\title{
Perangkat Penentu Kualitas Beras Ditinjau dari Kadar Air dan Berat Butir Menir Berbasis Arduino Uno
}

\author{
Mustofah $^{1}$, Pipit Utami ${ }^{2}$ \\ ${ }^{1}$ Program Studi Teknik Elektronika Fakultas Teknik Universitas Negeri Yogyakarta \\ ${ }^{2}$ Program Studi PendidikanTeknik Elektronika Fakultas Teknik Universitas Negeri Yogyakarta \\ E-mail: mustofah.2015@student.uny.ac.id
}

\begin{abstract}
Determining the quality of rice is something that must be done to maintain the quality of rice produced by farmers. Quality determinants used for this process can be relied on for rice properly and efficiently. Determination of air content using soil moisture sensor yl-69 and determination of grain weight using a load cell sensor that emits with an Arduino UNO microcontroller as a device controller device. System making method consists of needs, analytic requirements, block diagrams, system design, manufacturing tools, testing tools and tools. The test results show that the determinant of rice quality in terms of good air and weight with errors in the readings of soil moisture sensor yl-69 is $1.522 \%$ and the error in load cell reading is $0.431 \%$. The performance of this rice quality assessment device shows that the device can function properly in terms of the sensor's working measurement, the device for determining rice quality and the performance of all components in the device can run well.
\end{abstract}

Keywords: Quality of rice, Water Content, Grain, Arduino Uno

\begin{abstract}
ABSTRAK
Penentuan kualitas beras merupakan suatu hal yang harus dilakukan untuk menjaga kualitas beras hasil produksi petani. Perangkat penentu kualitas beras ini ditinjau dari aspek kadar air dan berat butir menir dibuat untuk petani atau pedagang agar dapat menentukan kualitas beras dengan baik dan efisien. Penentuan kadar air menggunakan sensor soil moisture yl-69 dan penentuan berat butir menir menggunakan sensor load cell yang dihubungkan dengan mikrokontroler Arduino UNO sebagai piranti pengendali perangkat. Metode pembuatan sistem terdiri dari identifikasi kebutuhan, analisa kebutuhan, blok diagram, perancangan sistem, langkah pembuatan alat, spesifikasi alat dan pengujian alat. Hasil pengujian menunjukan bahwa perangkat penentu kualitas beras ditinjau dari kadar air dan berat butir menir berfungsi baik dengan error pada pembacaan sensor soil moisture yl-69 sebesar $1.522 \%$ dan error pada pembacaan load cell sebesar $0.431 \%$. Unjuk kerja dari perangkat penentu kualitas beras ini menunjukkan bahwa perangkat dapat berfungsi dengan baik dilihat dari segi kerja sensor untuk mengukur, perangkat untuk menentukan kualitas beras dan kinerja dari semua komponen dalam perangkat dapat berjalan dengan baik.
\end{abstract}

Kata kunci: Kualitas beras, Kadar Air, Butir menir, Arduino Uno

\section{PENDAHULUAN}

Biji padi (beras) merupakan makanan pokok di Indonesia. Konsumsi beras di Indonesia mencapai 1,57 per kapita per minggu pada tahu 2017 [1]. Peningkatan konsumsi beras tersebut harus tetap menjaga mutu kualitas beras dan gabah. Badan Urusan Logistik (BULOG) merupakan badan yang mengurus logistik dan pangan. Salah satu tugas BULOG adalah mengawasi kualitas beras yang dihasilkan oleh petani dan yang didistribusikan oleh pedagang. Terdapat beberapa persyaratan untuk menentukan kualitas beras. Persyaratan kualitas beras yang diakui BULOG terdiri atas: (1) kadar air maksimum (14\%); (2) butir patah/ broken maksimum (20\%); (3) derajat sosoh minimum (95\%); dan (4) butir menir maksimum (2\%) [2]. 
Kadar air merupakan salah satu karakteristik yang sangat penting pada bahan pangan, karena air dapat mempengaruhi penampakan, tekstur, dan cita rasa pada bahan pangan. Kadar air merupakan pemegang peranan penting karena aktivitas air menyebabkan terjadinya proses pembusukan. Kerusakan bahan makanan pada umumnya merupakan proses mikrobiologis, kimiawi, enzimatik atau kombinasi antara ketiganya. Berlangsungnya ketiga proses tersebut memerlukan ketersediaan air dalam bahan pangan [3]. Hal ini yang melatar belakangi penulis memasukan aspek kadar air dalam perangkat yang dibangun. Beras menir merupakan salah satu hasil samping proses penggilingan beras selain bekatul. Penampakan menir sama halnya beras patah, namun menir berukuran lebih kecil dari $2 / 10$ bagian beras utuh [4]. Hal ini yang melatar belakangi penulis memasukan aspek butir menir dalam perangkat yang dibangun. Dua aspek lainya yaitu butir patah dan derajat sosoh tidak diikut sertakan dalam perangkat. Derajat sosoh merupakan garis putih yang terdapat pada beras dan untuk melihatnya dengan kaca pembesar dan memiliki batas minimum 95\%. Derajat sosoh tidak diikutsertakan karena menurut penulis, untuk menganalisi derajat sosoh harus dilakukan dengan pengamatan langsung agar lebih detail karena berkaitan dengan penampakan beras. Sedangkan butir patah tidak dimasukan karena butir patah bukan termasuk sampah hasil penggilingan dan butir patah juga merupakan beras yang masih layak untuk dimasak menjadi nasi.

Dari empat syarat kualitas beras yang diakui BULOG untuk menguji beras dari petani dan mengedarkannya kembali ke masyarakat, umumnya pedagang dan petani hanya berfokus pada kadar air beras karena kadar air yang sesuai akan memiliki daya simpan yang lama. Tetapi alat pengukur kadar air atau moisture meter digital yang ada di pasaran memiliki harga yang cukup mahal membuat pedangang dan petani memilih menggunakan cara-cara manual untuk mengetahuinya yaitu dengan menggunakan indra perasa mereka. Hal tersebut memungkinkan terjadinya human error dan hasil kualitas beras menjadi tidak jelas yang beresiko beras ditolak oleh BULOG, sehingga beras gagal mendapat izin untuk didistribusikan ke lain daerah. Tabel 1 menunjukkan analisis cara penentuan kadar air dan butir menir secara konvensional dan alternatif yang dapat diupayakan. Analisis diperoleh dari observasi di BULOG.

Tabel 1. Analisis Perangkat

\begin{tabular}{|c|c|c|}
\hline Parameter & Konvensional & $\begin{array}{c}\text { Upaya } \\
\text { alternatif }\end{array}$ \\
\hline $\begin{array}{l}\text { 1. Kadar } \\
\text { Air }\end{array}$ & $\begin{array}{l}\text { Pengukuran } \\
\text { menggunakan grain } \\
\text { moisture sensor } \\
\text { sebanyak } 10 \% \text { dari } \\
\text { total beras sebagai uji } \\
\text { sampel. }\end{array}$ & $\begin{array}{l}\text { Alternative } \\
\text { sensor lain: } \\
\text { perang kat } \\
\text { dan sensor } \\
\text { soil moisture } \\
\text { yl69 }\end{array}$ \\
\hline $\begin{array}{l}\text { 2. Butir } \\
\text { Menir }\end{array}$ & $\begin{array}{l}\text { Prosedur: } \\
\text { - Mengukur } 10 \% \text { dari } \\
\text { total beras sebagai } \\
\text { uji sample. } \\
\text { - Diayak untuk } \\
\text { memisahkan butir } \\
\text { menir dan utuh. } \\
\text { - Ditimbang dan } \\
\text { dihitung. }\end{array}$ & $\begin{array}{l}\text { Penyingkatan } \\
\text { tahapan } \\
\text { pengukuran: } \\
\text { perangkat } \\
\text { dan } \\
\text { timbangan } \\
\text { digital load } \\
\text { cell }\end{array}$ \\
\hline
\end{tabular}

Pada penelitian sebelumnya terkait pengukuran kadar air menggunakan sensor fotodioda masih menghasilkan error sebesar $3,04 \%$ [5]. Pada perangkat prinsip kerja sensor tidak sesuai dengan sensor konvensional milik petani yang menggunakan perangkat digital moisture meter dan masih memiliki error yang tinggi. Tujuan penelitian ini adalah melakukan analisis, merancang dan membuat perangkat penentu kualitas beras ditinjau dari kadar air dan berat butir menir berbasis Arduino UNO. Pembuatan perangkat tersebut bertujuan mempermudah petani untuk menentukan kualitas beras yang ideal secara efisien, agar resiko beras ditolak oleh BULOG berkurang.

Arduino UNO adalah board mikrokontroler berbasis ATmega328. Kelebihan Arduino diantaranya adalah tidak perlu perangkat chip programmer karena didalamnya sudah ada bootloader yang akan menangani 
upload program dari komputer, Arduino sudah memiliki sarana komunikasi USB, sehingga pengguna laptop yang tidak memiliki port serial/RS323 bisa menggunakannya. Bahasa pemrograman relatif mudah karena software Arduino dilengkapi dengan kumpulan library yang cukup lengkap, dan Arduino memiliki modul siap pakai (shield) yang bisa ditancapkan pada board Arduino [6]. Sensor soil moisture yl69 merupakan sensor yang mengukur kelembaban dengan menggunakan probe.

Sensor soil moisture yl-69 merupakan sensor yang terdiri dari dua probe untuk melewatkan arus melalui tanah, kemudian membaca resistansinya untuk mendapatkan nilai tingkat kelembaban [7]. Sensor kelembaban soil moisture yl-69 terdapat sebuah modul yang didalamnya terdapat IC LM393 yang berfungsi untuk proses pembanding offset renda yang lebih rendah dari $5 \mathrm{mV}$ yang stabil dan presisi [8]. Sensor load cell merupakan sensor yang dirancang untuk mendeteksi tekanan atau berat sebuah beban dapat diaplikasikan pada jembatan timbangan yang berfungsi untuk menimbang berat dari truk pengangkut bahan baku [9].

Modul HX711 merupakan modul amplifier yang biasa digunakan dalam rangkaian timbangan digital load cell sebagai modul konversi sinyal analog ke digital pada load cell. Memiliki presisi tinggi 24 ADC high gain input yang didesain untuk berbagai sensor berjenis Bridge. Dengan dua channel A dan B (fix gain 32) yang berkomunikasi secara multipleks, modul ini dapat di program untuk gain 128 atau $64(20 \mathrm{mV}$ atau $40 \mathrm{mV})$ [10]. LCD (Liquid Crystal Display) adalah suatu jenis media tampil yang menggunakan kristal cair sebagai penampil utama. LCD yang digunakan ialah LCD dot matrik dengan jumlah karakter 2 x 16 untuk menampilkan status kerja alat. Modul I2C LCD adalah modul LCD yang dikendalikan secara serial sinkron dengan protokol I2C/IIC (Inter Integrated Circuit) atau TWI (Two Wire Interface).

Error adalah sebuah nilai variasi dalam sebuah pengukuran dimana nilai variasi tersebut merupakan selisih yang diperoleh dari nilai terukur dan nilai sebenarnya. Perubahan pada reaksi alat ukur dibagi oleh hubungan perubahan aksinya dan dikali 100\% [11]. Hasil perangkat penentu kualitas beras ditinjau dari kadar air dan berat butir menir yang dibangun telah menggunakan komponen dan bahan yang sesuai dengan kebutuhan petani terkait penentuan kualitas beras.

\section{METODE}

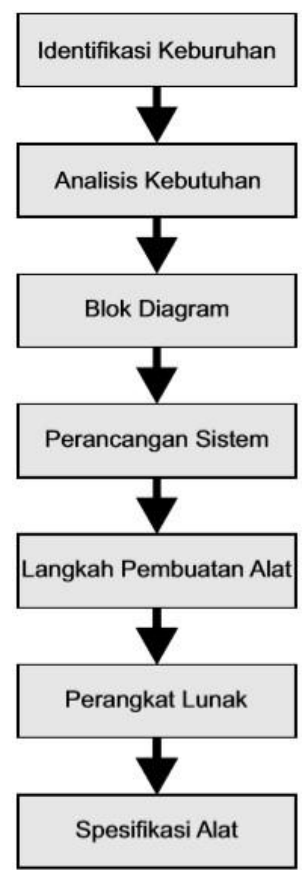

Gambar 1. Tahapan perancangan

Gambar 1 merupakan tahapan perancangan perangkat penentu kualitas beras ditinjau dari kadar air dan berat butir menir berbasis Arduino UNO. Identifikasi dan analisis kebutuhan komponen dan perangkat pendukung diantaranya yaitu: (1) Sensor soil moisture yl-69 sebagai sensor pengukur kadar air untuk menentukan kualitas beras; (2) Sensor load cell sebagai sensor pengukur berat butir menir; (3) Push button merupakan switch on/off digunakan sebagai inputan pada perangkat dan mengontrol kerja perangkat; (4) Arduino UNO digunakan sebagai pengolahan data yang ditampilkan informasinya di LCD; (5) LCD 16x2 digunakan sebagai serial display atau penampil informasi pada perangkat; (6) Catu daya 5V DC digunakan untuk mensuplai daya ke arduino, sensor dan komponen lainnya; (7) Kabel penghubung atau 
jumper digunakan untuk menghubungkan komponen dengan mikrokontroler Arduino UNO; (8) Box alat dengan akrilik $5 \mathrm{~mm}$ digunakan untuk wadah dari semua komponen dan wadah meletakan sample beras; dan (9) Motor servo sg90 digunakan sebagai penggerak pengayak pada proses pengayakan pada perangkat.

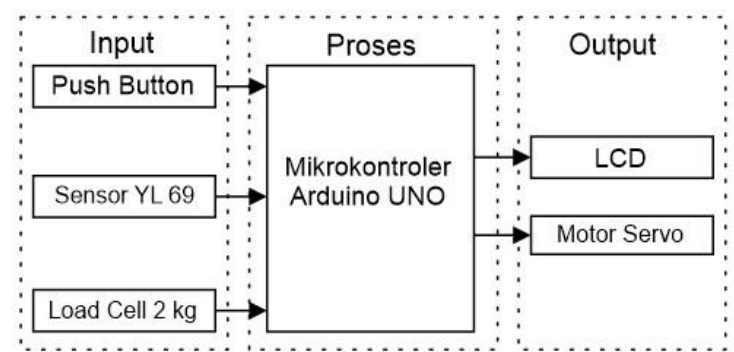

Gambar 2. Blok Diagram Sistem

Blok diagram sistem dapat dilihat pada Gambar 2. Terdapat beberapa masukan yaitu Push button sebagai inputan yang mengontrol kerja perangkat, sensor soil moisture yl-69 sensor pengukur kadar air dan sensor load cell sebagai sensor berat untuk mengukur berat butir menir. Blok proses merupakan bagian pengolah data hasil dari pengukuran sensor dan perintah dari push button. Data akan disimpan dan diproses untuk menentukan kualitas beras ditinjau dari kadar air dan berat butir menir. Pada alat ini menggunakan catu daya 5V DC digunakan untuk tegangan pada Arduino UNO, sensor dan komponen lainnya. Tiga blok pada perangkat ini yaitu blok sensor soil moisture yl69, blok sensor load cell dan blok sistem mikrokontroler.

Rangkaian Utama Modul sensor soil moisture yl-69 yaitu menggunakan rangkaian komparator dengan menggunakan IC LM 393. IC LM 393 merupakan IC yang memiliki dua Op Amp. IC Komparator atau IC pembanding adalah sebuah IC yang berfungsi untuk membandingkan dua macam tegangan yang terdapat pada kedua inputnya. Komparator memiliki 2 buah input dan sebuah output. IC LM393 bekerja dengan tegangan input $-3 \mathrm{v}$ sampai $+36 v$. Pada kedua input tegangan masuk diturunkan tegangannya sesuai dengan kebuthan input LM 393. Komparator akan bekerja dengan membandingkan tegangan input V1 dengan tegangan Vref. Tegangan Vref berubah jika diberi tegangan $\mathrm{V}+/ \mathrm{V}$ - berubah tergantung pengukuran sensor soil moisture yl69 dengan menggunakan resistansi listrik. Apabila pada Vref diberi tegangan positif, maka gelombang input Vref berada didaerah 0 sampai - Vref dan outputnya akan dibuat mencapai Vo maksimum tegangan negatif (-Vo). Sedangkan, Apabila pada Vref diberi tegangan negatif, maka pada saat gelombang input melebihi batas tegangan negatif (-Vref) dan outputnya akan dibuat tinggi mencapai tegangan batas maksimum tegangan output positif (+Vo).

Modul HX711 adalah presisi 24-bit analog- to-digital converter (ADC) dirancang untuk menimbang skala dan aplikasi kontrol industri untuk antarmuka langsung dengan sensor jembatan wheatson pada load cell atau strain gauge. Multiplexer masukan memilih chanel A atau B sebagai input diferensial ke lownoise amplifier penguat yang dapat diprogram (PGA). Channel A dapat diprogram dengan perolehan 128 atau 64, sesuai dengan input diferensial skala penuh tegangan $\pm 20 \mathrm{mV}$ atau \pm $40 \mathrm{mV}$, kapan pasokan $5 \mathrm{~V}$ terhubung ke daya analog AVDD pin persediaan. Channel B memiliki perolehan tetap 32. On-regulator catu daya chip menghilangkan kebutuhan untuk regulator pasokan eksternal untuk menyediakan analog daya untuk ADC dan sensor. Masukan jam adalah fleksibel. Bisa dari sumber jam eksternal, kristal, atau osilator on-chip yang tidak membutuhkan komponen eksternal. Onchip power-circuit on-reset menyederhanakan antarmuka digital inisialisasi. Rangkaian keseluruhan dan konfigurasi pin arduino tersaji pada Gambar 4.

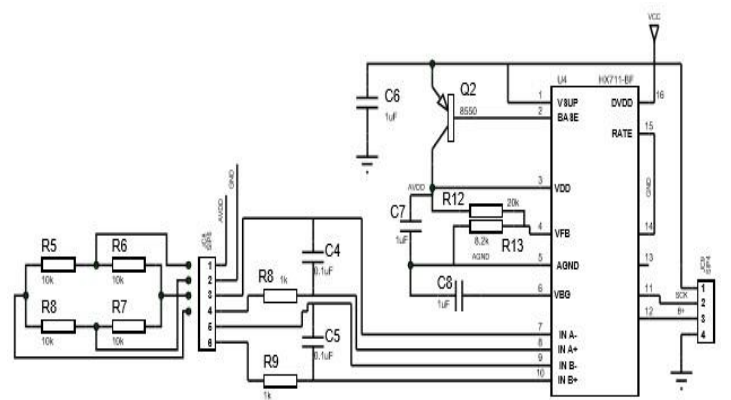

Gambar 3. Rangkaian Load Cell dan Modul HX 711 


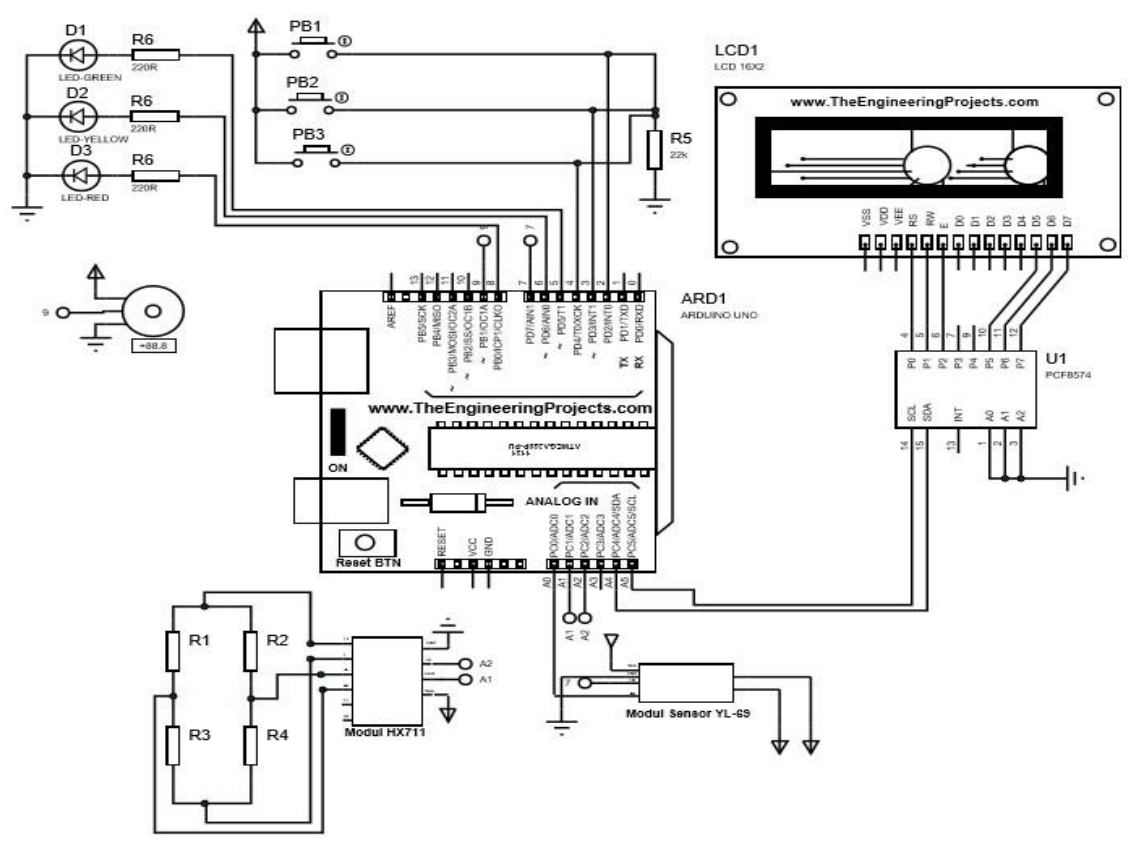

(a)

\begin{tabular}{|c|c|l|}
\hline No. & I/O & \multicolumn{1}{|c|}{ Keterangan } \\
\hline 1 & A0 & $\begin{array}{l}\text { Output analog } \\
\text { sensor soil } \\
\text { moisture yl-69 }\end{array}$ \\
\hline 2 & A1 & $\begin{array}{l}\text { Clock sensor } \\
\text { Load Cell }\end{array}$ \\
\hline 3 & A2 & $\begin{array}{l}\text { Dout sensor } \\
\text { Load Cell }\end{array}$ \\
\hline 4 & A4 & $\begin{array}{l}\text { SCL modul } \\
\text { I2C lcd }\end{array}$ \\
\hline 5 & A5 & $\begin{array}{l}\text { SDA modul } \\
\text { I2C lcd }\end{array}$ \\
\hline 6 & 2 & Push Button 1 \\
\hline 7 & 3 & Push Button 2 \\
\hline 8 & 4 & Push Button 3 \\
\hline 9 & 5 & Led hijau \\
\hline 10 & 6 & Led biru \\
\hline 11 & 7 & $\begin{array}{l}\text { Output Digital } \\
\text { sensor soil } \\
\text { moisture yl-69 }\end{array}$ \\
\hline 12 & 8 & Led merah \\
\hline 13 & 9 & $\begin{array}{l}\text { Data motor } \\
\text { servo }\end{array}$ \\
\hline
\end{tabular}

(b)

Gambar 4. (a) Rangkaian Blok Sistem dan (b) konfigurasi pin arduino

Alat ini bekerja dengan sumber tegangan 5 volt, ketika alat sudah dalam keadaan on dan source code program sudah terupload pada Mikrokontroler Arduino UNO maka alat sudah siap difungsikan. Sesuai rangkaian nantinya alat ini bekerja dengan push button sebagai kontrolnya. Dengan menekan push button 1 untuk menghitung Data1 dengan sensor load cell dan sensor soil moisture yl-69, kemudian push button 2 untuk mengukur Data2 dengan sensor load cell dan sensor soil moisture yl-69 dan mengaktifkan motor servo, terakhir push button 3 untuk menyeleseikan pengukuran jika terjadi kesalahan pengambilan uji sample beras, dan kemudian hasil akan tertampil di LCD. Penggunaan pin Arduino sesuai dengan komponen yang dibutuhkan penulis yaitu menghabiskan 13 input (plus vcc dan ground). Dalam pembuatannya terbagi dalan tiga bagian seperti Gambar 5.

Perancangan software merupakan langkalangkah terkait perangkat lunak yang ada untuk membangun perangkat seperti Gambar 5 . Perancangan software ini terbagi dalam 3 langkah sebagai berikut: (1) Membuat flowchart terbagi menjadi flowchart program alat dan flowchart alat. Flowchart program alat digunakan untuk memudahkan dalam menyusun program arduino. Sedangkan flowchart alat untuk melihat cara kerja atau cara pengoperasian alat; (2) Memprogram arduino dalam perencanaanya penulis menggunakan mikrokontroler Arduino UNO dan untuk memprogram menggunakan software Arduino $I D E$; dan (3) Mendesain alat dilakukan dalam dua langkah yaitu mendesain box alat dan mendesain PCB. Mendesain box alat dilakukan untuk membuat gambaran dari perangkat yang akan dibuat dan box alat terbuat dari bahan akrilik. Mendesain PCB untuk membuat desain jalur rangkaian pada PCB.

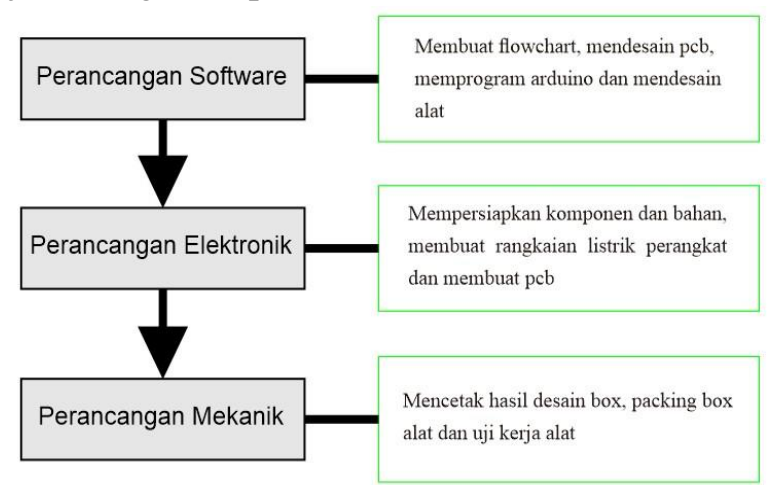

Gambar 5. Langkah pembuatan 
Perancangan elektronik merupakan langkah-langkah terkait elektronika dalam pembuatan alat. Perancangan elektronik ini terbagi dalam 3 langkah sebagai berikut: (1) Mempersiapkan komponen yang akan digunakan penulis seperti sensor, mikrokontroler dan motor. Mempersiapkan bahan untuk membuat perangkat yaitu menggunakan bahan akrilik; (2) Membuat rangkain listrik yang akan menghubungkan komponen-komponen yang digunakan; dan (3) Membuat PCB melalui beberapa langkah yaitu mencetak desain PCB, melarutkan PCB dan mengaplas untuk membersihkan jalur rangkaian PCB.

Perancangan Mekanik terkait hardware dalam pembuatan alat. Perancangan mekanik ini terbagi dalam 3 langkah sebagai berikut: (1) Mecetak desain box yang telah dibuat akan dicetak untuk merealisasikan desain yang telah dibuat. Desain box akan dicetak diatas bahan akrilik; (2) Packing box alat dilakukan setelah semua bahan sudah siap, maka langkah ini dilakukan untuk menyatukan semuanya menjadi satu wadah box alat; dan (3) Uji kerja alat dilakukan untuk mengetahui apakah perangkat yang telah dibangun sesuain dengan harapan dan sesuai dengan perancangan.

Flowchart program pada Gambar 6 merupakan alur kerja dari perangkat yang akan dibuat penulis. Program dimulai dengan menginisialisasi default kadar air dengan nilai 14 dan butir menir 2. Kemudian ketika push button 1 aktif maka sensor kadar air mengukur beras dan sensor berat akan mengukur berat awal beras yang akan diuji kualitas berasnya. Kemudian ketika push button 2 aktif maka pengayak akan aktif dengan penggerak motor servo dan sensor berat akan mengukur berat butir menir. Kemudian ketika push button 3 aktif maka pengukuran sebelumnya akan dibandingkan. Terakhir output dari semua pengukuran apabila kadar kurang dari 14 dan butir dan butir menir kurang dari 2 maka kualitas beras baik dan sebaliknya maka kualitas beras buruk. Program selesei dan akan diulang jika push button ditekan kembali.

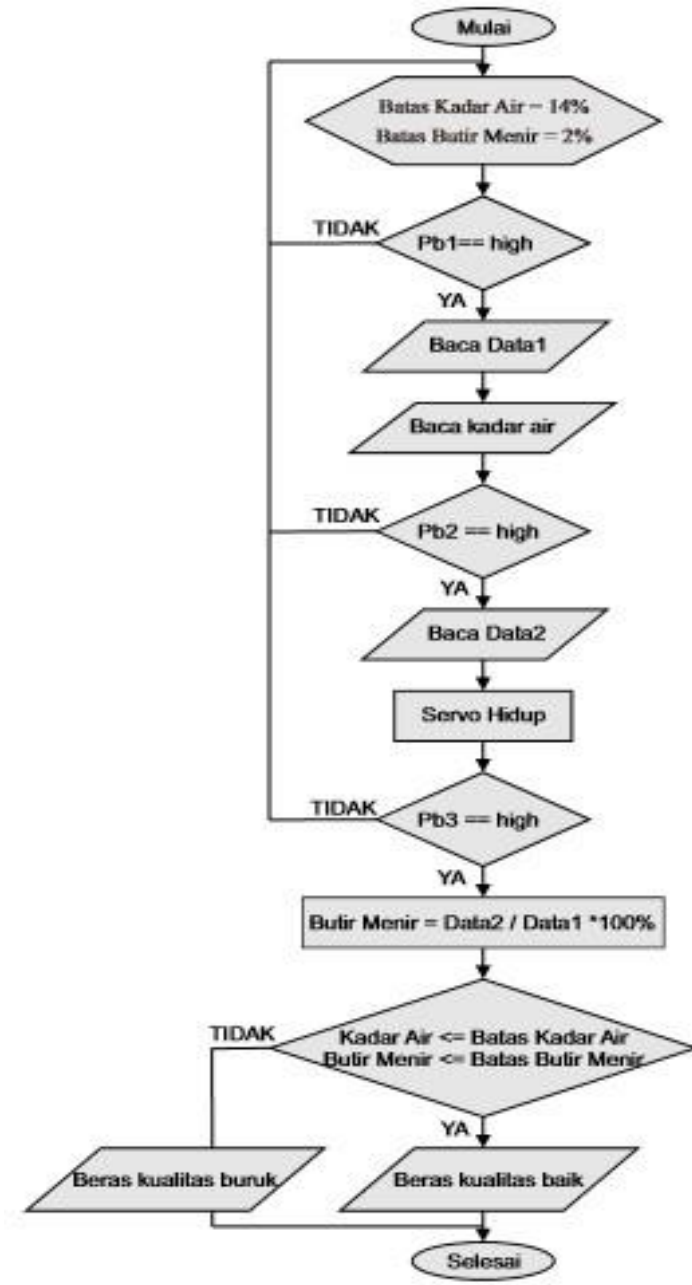

Gambar 6. Flowchart Program

Spesifikasi alat terdiri dari desain layout perangkat, desain layout pengayak dan desain layout load cell. Desain Box untuk Perangkat Penentu Kualitas Beras Ditinjau Dari Kadar Air dan Berat Butir Menir Berbasis Arduino UNO dapat dilihat pada Gambar 7(a). Box berukuran tidak terlalu kecil untuk memberi ruang pada proses pengayakan dan box tidak terlalu besar dengan harapan bisa menjadi alat yang portabel. Perangkat ini dibangun dengan menggunakan bahan akrilik. Pada Gambar 7(b) layout pengayak dilihat dari tampak atas yang berisi motor servo sebagai penggerak pengayak dan ayakan dengan diameter $1.70 \mathrm{~mm}$ sesuai dengan aturan cara menghitung butir menir dengan pengayak. Pada gambar 7(c) layout load cell dilihat dari tampak samping dengan tambahan papan akrilik pada bagian bawah dan atas load cell untuk memudahkan pengukuran berat. 


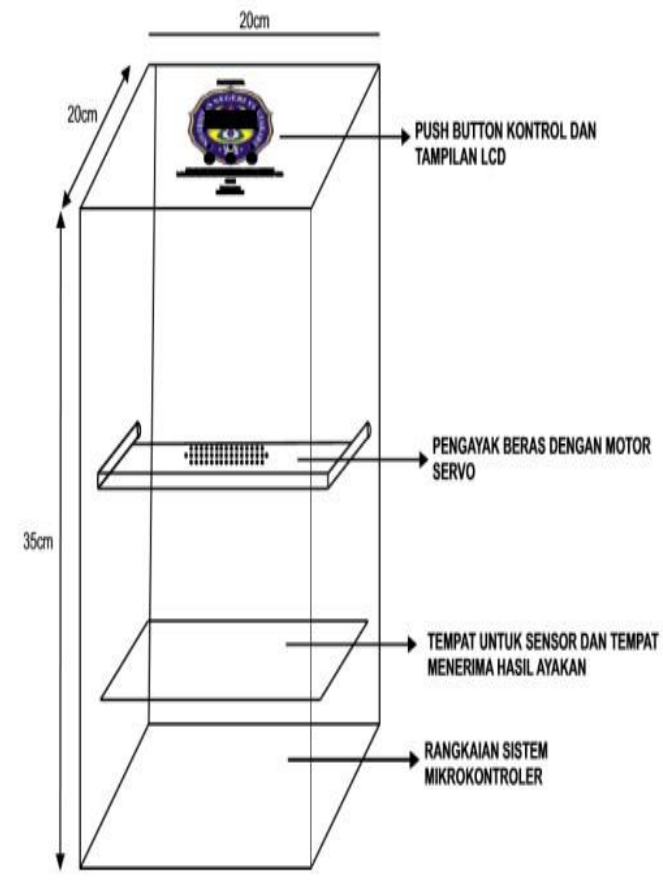

(a)

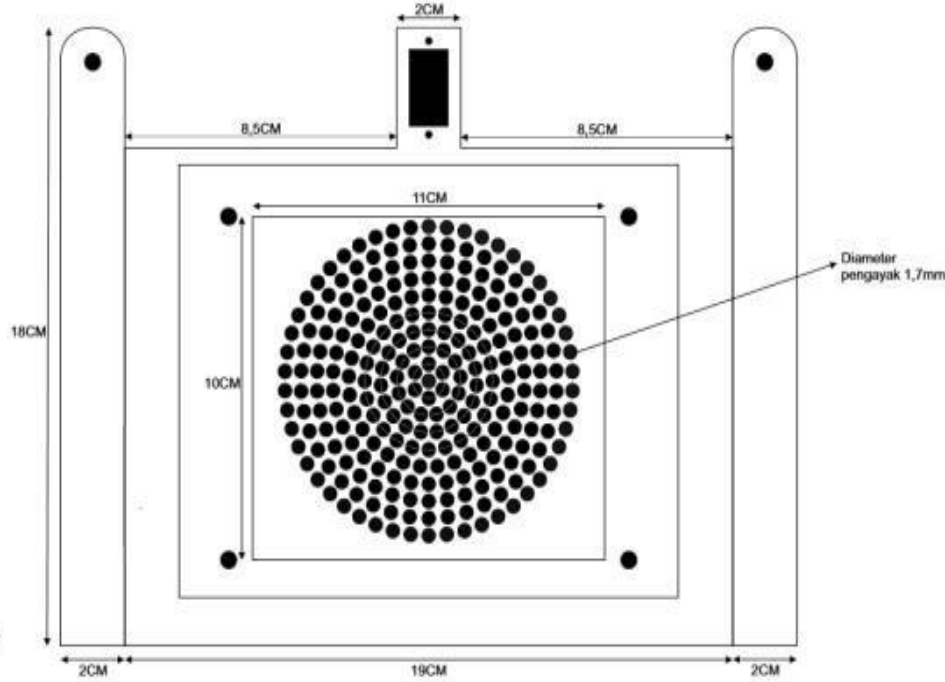

(b)

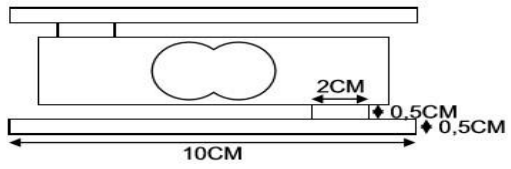

(c)

Gambar 7. (a) Layout perangkat, (b) Layout pengayak dan (c) Layout Load Cell

\section{HASIL DAN PEMBAHASAN}

Pengujian perangkat terdiri atas pengujian tegangan yang meliputi tegangan catu daya dan tegangan mikrokontroler, pengujian kerja sensor, dan pengujian pengiriman data hardware pada website. Tegangan catu daya perangkat penentu kualitas beras ditinjau dari kadar air dan berat butir menir berbasis Arduino $U N O$ membutuhkan tegangan $5 \mathrm{~V}$ DC untuk dapat beroperasi. Adaptor charger handphone digunakan untuk menstabilkan tegangan $220 \mathrm{~V}$ AC menjadi DC 5 V. Sesuai dengan keluaran yang tersedia pada adaptor hanya $5 \mathrm{~V}$ DC maka tidak dilakukan uji tegangan pada catu daya. Pengujian tegangan mikrokontroler tanpa beban menghasilkan tegangan sesuai dengan tegangan yang tersedia pada Arduino UNO yaitu 5 Volt pada pin 5 volt, 3,3 volt pada pin 3,3 volt, dan 4,8 volt pada pin Vin. Pengujian titik kerja sensor adalah untuk melihat apakah sensor bekerja atau tidak, karena apabila sensor bekerja dengan baik maka akan menghasilkan keluaran yang sesuai dengan keadaan sensor.

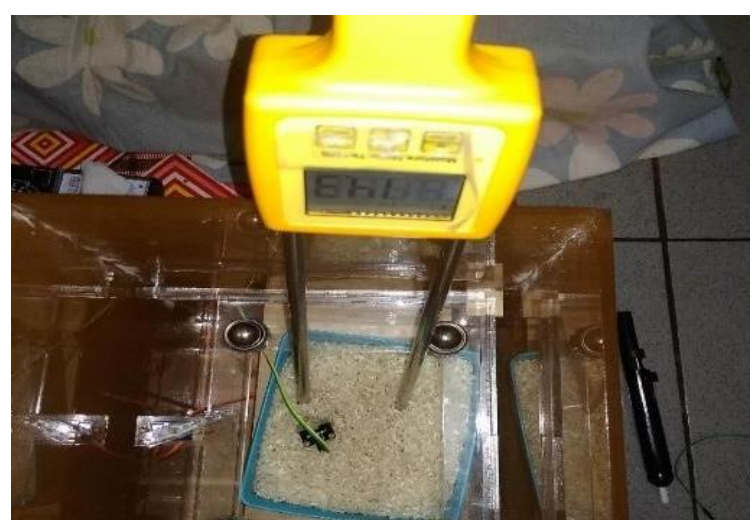

Gambar 8. Pengujian sensor soil moisture yl69 dengan moisture tk 100 s

Pengujian sensor soil moisture yl-69 dilakukan terhadap 10 uji sample beras yang bervariasi dan membandingkannya dengan perangkat sensor moisture meter tk100s (Gambar 8). Pengujian dilakukan untuk melihat kinerja sensor. Pada pengujian Input tegangan Sensor soil moisture yl-69 menggunakan input terukur $3 \mathrm{~V}$ pada pin $3.3 \mathrm{~V}$ di Arduino UNO. Hasil tersaji pada Tabel 2, dimana Eab untuk Eabsolute, Er untuk Error dan Ak untuk akurasi. 
Tabel 2. Hasil Pengujian Sensor Soil Moisture yl-69

\begin{tabular}{ccccccc}
\hline No & $\begin{array}{c}\text { ADC } \\
\text { Sensor }\end{array}$ & $\begin{array}{c}\text { sm } \\
\text { yl69 }\end{array}$ & $\begin{array}{c}\text { Mm } \\
\text { tk100s }\end{array}$ & Eab & $\begin{array}{c}\text { Er } \\
(\%)\end{array}$ & Ak (\%) \\
\hline 1 & 329 & 11 & 11,2 & 0.2 & 1.78 & 98.22 \\
2 & 375 & 14 & 14.3 & 0.3 & 2.09 & 97.91 \\
3 & 420 & 15 & 14.8 & 0.2 & 1.35 & 98.65 \\
4 & 333 & 11 & 11.2 & 0.2 & 1.78 & 98.22 \\
5 & 621 & 20 & 20.4 & 0.4 & 1.96 & 98.04 \\
6 & 483 & 16 & 16.3 & 0.3 & 1.84 & 98.16 \\
7 & 545 & 18 & 18.1 & 0.1 & 0.55 & 99.45 \\
8 & 330 & 11 & 11.1 & 0.1 & 0.90 & 99.10 \\
9 & 365 & 13 & 13.3 & 0.3 & 2.25 & 97.75 \\
10 & 378 & 14 & 14.3 & 0.3 & 0.72 & 99.28 \\
\hline
\end{tabular}

Tabel 2 menunjukkan bahwa pengujian dari sensor soil moisture yl69 dan sensor load cell telah berhasil dilakukan dan sesuai yang diharapkan. Data yang diperoleh pengujian kerja soil moisture yl-69 menghasilkan error minimum sebesar $0.55 \%$ dan error maksimun sebesar $2.25 \%$. Sedangkan rata-rata error sebesar $1.522 \%$ yang tergolong dalam klas alat ukur $\pm 1.5 \%$. Pada pemilihan alat ukur dilihat dari kepentingan pengukuran, peralatan ataupun perencanaan dalam penggunaan digolongkan dalam 4 golongan sebagai: (1) alat-alat ukur dari kelas $0.05,0.1$ dan 0.2 ; (2) alat-alat ukur dari kelas 0.5 ; (3) alat-alat ukur dari kelas 1.0 dan (4) alat-alat ukur dari kelas 1.5 atau 2.5 atau 5 [12]. Dari penggolongan tersebut, sensor soil moisture $y l$-69 tergolong dalam klas alat ukur \pm 1.5 yaitu dimana alat-alat ukur ini dipergunakan pada panil-panil dimana presisi serta ketelitian daripada alat ukur ini tidak begitu penting.

Pada perangkat ini juga memiliki akurasi sebesar $98.478 \%$ dan standar error sebesar standar error sebesar 0.389 cukup baik untuk mengetahui error secara spesifik. Sedangkan, data yang diperoleh pengujian kerja sensor load cell menghasilkan error minimum sebesar $0 \%$ dan error maksimum sebesar $0.6 \%$. Sedangkan rata-rata error sebesar $0.431 \%$ yang tergolong dalam klas alat ukur $\pm 0.5 \%$. Pada perangkat ini juga memiliki akurasi sebesar $98.478 \%$ dan standar error sebesar standar error sebesar 0.207 cukup baik untuk mengetahui error secara spesifik. Uji linieritas sensor terhadap jarak menghasilkan kesimpulan bahwa sensor soil moisture yl-69 dan load cell bersifat linier. Hal ini dibuktikan dengan perolehan grafik linieritas sensor pada Gambar 9. Uji linearitas sensor ini dimaksudkan untuk melihat hasil pembacaan sensor yang masuk diproses oleh mikorkontroler bersifat linear atau tidak. Pengujian ini dilakukan dengan cara melihat pembacaan sensor dan membandingkannya dengan sensor konvensional.

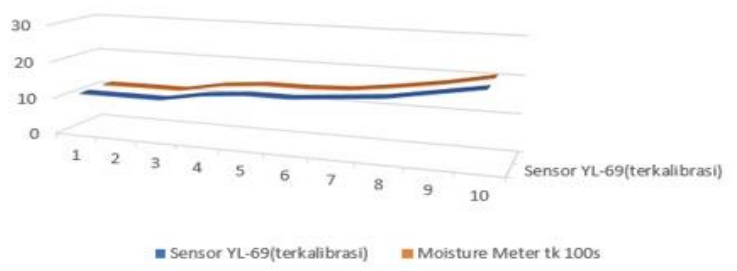

Gambar 9. Grafik Linieritas pengujian sensor yl 69 terhadap sensor tk100s

Pengujian sensor timbangan load cell dilakukan terhadap 10 uji sample beras yang bervariasi beratnya dan dibandingankan dengan timbangan digital SF-400 (Gambar 10). Pengujian dilakukan untuk melihat kinerja sensor. Pada pengujian Input tegangan sensor soil soil moisture yl-69 menggunakan input terukur $4.8 \mathrm{~V}$ pada pin $5 \mathrm{~V}$ di Arduino UNO. Hasil tersaji pada Tabel 3, dimana LC untuk Load Cell, SF untuk SF-400, Eab untuk Eabsolute, Er untuk Error dan Ak untuk akurasi.

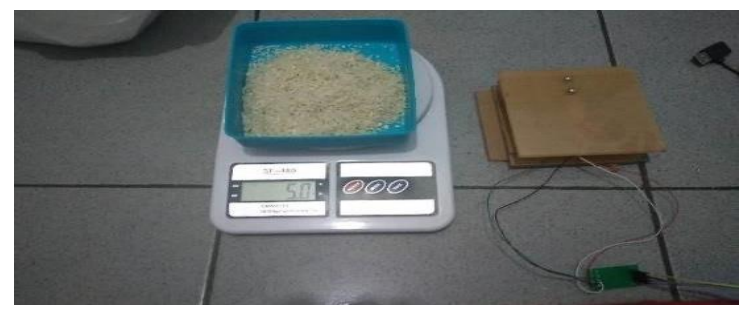

Gambar 10. Pengujian load cell dengan timbangan digital SF-400

Tabel 3. Hasil Pengujian Sensor Load Cell

\begin{tabular}{cccccc}
\hline No. & $\begin{array}{c}\text { LC } \\
(\mathrm{gr})\end{array}$ & $\begin{array}{c}\text { SF } \\
(\mathrm{gr})\end{array}$ & Ea & Er $(\%)$ & $\mathrm{Ak}(\%)$ \\
\hline 1 & 1.5 & 1,5 & 0 & 0 & 100 \\
2 & 5.05 & 5 & 0.05 & 1 & 99 \\
3 & 10.01 & 10 & 0.01 & 0.1 & 99.9 \\
4 & 15.07 & 15 & 0.07 & 0.46 & 99.54 \\
5 & 20.1 & 20 & 0.1 & 0.5 & 99.5 \\
6 & 25.15 & 25 & 0.15 & 0.6 & 99.4 \\
7 & 30.13 & 30 & 0.13 & 0.43 & 99.57 \\
8 & 35.12 & 35 & 0.12 & 0.34 & 99.66 \\
9 & 40.17 & 40 & 0.17 & 0.42 & 99.58 \\
10 & 45.21 & 45 & 0.21 & 0.46 & 99.54 \\
\hline
\end{tabular}


Dari Tabel 3 pengujian sensor load cell diatas diketahui bahwa sensor load cell memiliki rerata error $0.431 \%$. Dari penggolongan alat ukur, sensor load cell tergolong dalam klas alat ukur \pm 0.5 [12]. Hal tersebut menunjukkan bahwa alat ukur tersebut mempunyai ketelitian dan presisi dan ketelitian pada tingkat berikutnya dari kelas 0.2 dan dipergunakan untuk pengukuranpengukuran presisi. Pada umumnya pada alat portable dalam kelas ini. Selain itu pengujian load cell memiliki akurasi sebesar $98.478 \%$. Sensor load cell tergolong baik sebagai alat ukur berat atau pengganti timbangan digital yang akan ada dalam perangkat penulis dikarenakan sesuai standar batas alata-lat ukur. Linieritas sensor ditunjukkan pada Gambar 11. Sensor soil moisture yl-69 mengalami kenaikan nilai output yang sesuai dengan sensor Moisture Meter tk 100s dan sensor load cell juga mengalami kenaikan nilai output yang sesuai dengan timbangan digital SF-400.

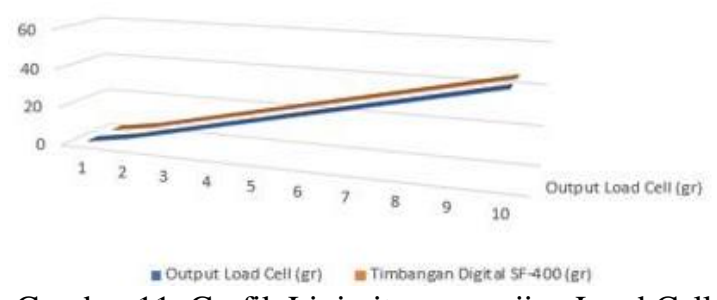

Gambar 11. Grafik Linieritas pengujian Load Cell dengan Timbangan Digital SF-400

Pengujian LCD ini dimaksudkan untuk membandingkan tampilan LCD dengan keadaan real pada perangkat. Pengujian tersaji pada Tabel 4. Hasil menunjukkan bahwa LCD berfungsi dengan baik sebagai penampil informasi.

Tabel 4. Hasil Pengujian LCD

\begin{tabular}{|c|c|c|}
\hline yl69 & Load cell & Tampilan LCD \\
\hline \multirow[t]{3}{*}{11} & Berat awal $=5.05$ & Kadar Air 11 \\
\hline & Berat menir $=1.52$ & Berat awal $=5.05$ \\
\hline & & Berat menir $=1.52$ \\
\hline \multirow[t]{3}{*}{12} & Berat awal $=5.25$ & Kadar Air 12 \\
\hline & Berat menir $=1.53$ & Berat awal $=5.25$ \\
\hline & & Berat menir $=1.53$ \\
\hline \multirow[t]{3}{*}{14} & Berat awal=5.37 & Kadar Air 14 \\
\hline & Berat menir $=1.53$ & Berat awal=5.37 \\
\hline & & Berat menir $=1.53$ \\
\hline
\end{tabular}

Uji hasil bentuk perangkat dilakukan untuk melihat bentuk fisik dari perangkat apakah perangkat yang dibangun penulis sesuai harapan dan sesuai dengan bentuk desain awal perangkat.

Tabel 5. Uji fungsionalitas perangkat (B: berhasil; TB: tidak berhasil)

\begin{tabular}{llll}
\hline No. & Perangkat & B & TB \\
\hline $1 \quad \begin{array}{l}\text { Perangkat menyala, LCD menyala } \\
\text { Sampel beras dimasukan kedalam }\end{array}$ & $\sqrt{ }$ & \\
& perangkat, Push Button 1 ditekan, \\
2 & maka sensor soil moisture yl-69 \\
& mengukur kadar air dan load cell \\
& mengukur berat awal \\
& Sampel beras dimasukan kedalam \\
& pengayak, Push Button 2 ditekan, \\
& maka proses pengayak berjalan \\
& dengan digerakan motor servo dan \\
& load cell mengukur berat butir menir \\
& Push Button 3 ditekan maka Arduino \\
& UNO akan mengolah data sensor soil \\
& moisture yl-69 dan load cell untuk \\
& $\sqrt{ }$ \\
& menentukan kualitas beras
\end{tabular}

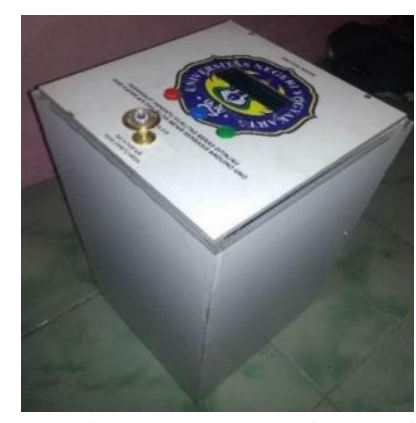

Gambar 12. Perangkat Jadi

Dari Gambar 12 terlihat bahwa bentuk fisik perangkat yang telah dibangun oleh penulis sesuai dengan bentuk desain awal perangkat. Perangkat penentu kualitas beras ditinjau dari kadar air dan berat butir menir telah berhasil dilakukan dan sesuai dengan kebutuhan petani untuk menentukan kualitas beras. Masukan pada perangkat terdiri atas push button sebagai kontrol perangkat, sensor soil moisture yl-69 untuk mengukur kadar air dan sensor load cell untuk mengukur berat butir menir. Mikrokontroler Arduino UNO untuk mengolah data dan menyimpan data. Mikrokontroler Arduino UNO pada perangkat penentu kualitas beras ditinjau dari kadar air dan berat butir menir memiliki beberapa fungsi, yaitu: (1) otak 
pengendali yang menghubungkan kerja dari setiap komponen yang digunakan; (2) sebagai pengolah data dari hasil pengukuran sensor; dan (3) penyimpanan sementara data hasil pengukuran sensor. Keluaran terdiri atas motor servo untuk melakukan proses pengayakan dan LCD sebagai serial display pada perangkat. Hasil uji, baik unjuk kerja perangkat maupun fungsional menujukkan bahwa perangakat sudah beroperasi sesuai target dan flowchart yang sesuai harapan.

\section{SIMPULAN}

Hasil analisis menunjukkan bahwa perlu adanya penyingkatan tahapan pengukuran kualitas beras. Perancangan perangkat berhasil direalisasikan, diantaranya: (1) perwujudan perangkat dengan penggunaan akrilik 5mm; (2) pengukuran kadar air menggunkan sensor soil moisture yl-69; (3) pengukuran berat butir menir menggunakan load cell; (4) Arduino UNO sebagai otak pengendali, pengolah data dan penyimpanan data pada perangkat; (5) motor servo untuk menggerakan pengayak, push button untuk kontrol kerja perangkat; dan (6) LCD sebagai serial display atau tampilan output dari perangkat. Unjuk kerja dari sensor soil moisture yl69 pada perangkat dapat bekerja dengan baik dan terdapat error pada pembacaan sensor sebesar $1,522 \%$ dan load cell bekerja dengan baik dan terdapat error pada pembacaan sensor sebesar $0,431 \%$. Error tersebut cukup baik karena sesuai dengan batas error maksimum yaitu 5\% untuk sebuah alat pengukur. Unjuk kerja dari perangkat penentu kualitas beras ditinjau dari kadar air dan berat butir menir berbasis Arduino UNO berdasarkan hasil pengujian yang telah dilaksanakan dapat berfungsi dengan baik dilihat dari segi kerja sensor untuk mengukur, kinerja dari semua komponen dalam perangkat dapat berjalan dengan baik dan penentuan kualitas beras. Terdapat beberapa saran untuk penelitian selanjutnya, yaitu: (1) mengganti pengayak yang lebih besar dan motor yang dapat meningkatkan gerakan ayakan agar proses pengayakan dapat merata dan penentuan berat butir menir lebih detail; dan (2) penggantian sensor sebagai upaya meminimalisir error dan meningkat presisi ketika melakukan pengukuran.

\section{DAFTAR PUSTAKA}

[1] Beritagar.id., "Konsumsi beras penduduk Indonesia, 2002-2017,” Lokadata, 2018. [Online]. Available: https://lokadata.beritagar.id/chart/preview/konsu msi-beras-penduduk-indonesia-2002-20171516257928. [Accessed: 25-Sep-2018].

[2] BULOG, "Perjanjian Jual Beli Beras. No. PJB00021/03/2010/41/KNK. 04/01/2018.," Yogyakarta, 2018.

[3] Winarno, Kandungan Air Beberapa Komoditi Bahan. Jakarta: Gramedia Pustaka Utama, 1977.

[4] Kadarisman, "Pengaruh Kelembapan Pangan dan Kadar Air Awal Gabah Varietas Cisadane Selama Penyimpanan Terhadap Perubahan Kadar Air, Rendemen Beras Giling, Beras Kepala, Beras Patah dan Menir," Fakultas Teknologi Pertanian IPB, 1986.

[5] S. F. Nasution, "Perancangan Alat Ukur Kadar Air pada Jagung (Zea mays L.) dengan Menggunakan Sensor YL-69 dan Tampilan LCD Berbasis Arduino Uno," Fakultas Matematika dan Ilmu Pengetahuan Alam USU, 2017.

[6] H. Guntoro, Y. Somantri, and E. Haritman, "Rancang Bangun Magnetic Door Lock Menggunakan Keypad Dan Solenoid Berbasis Mikrokontroler Arduino Uno," Electrans, vol. 12, no. 1, pp. 39-48, 2013.

[7] Roboticsbd, "YL-69 Soil Hygrometer Humidity \& Soil Moisture Detection Sensor For Arduino," Roboticsbd, 2018. [Online]. Available: https://store.roboticsbd.com/sensors/145-yl-69soil-humidity-moisture-sensor-bangladesh.html. [Accessed: 29-Aug-2018].

[8] E. Y. R. Dewi, "Rancang Bangun Sistem Penyiraman Sayur Sawi (Brassica chinensis L.) Menggunakan Sensor Kelembaban Dan Sensor Intensitas Cahaya Berbasisi Fuzzy Logic," Fakultas Teknik Universitas Jember, 2016.

[9] Robotshop, "Datasheet. 3133 - Micro Load Cell $(0-5 \mathrm{~kg})$ - CZL635," 2018.

[10]A. L. Khakim and S. Purbawanto, "Rancang Bangun Alat Timbang Digital Berbasis AVR Tipe ATmega32," J. Tek. Elektro, vol. 7, no. 2, 2015.

[11]A. C, “Pengertian Error," 2011. [Online]. Available:

https://www.scribd.com/doc/50770662/ BelajarInstrumentasi-Error-Pengukuran. [Accessed: 22Jul-2018].

[12]S. Sapiie and O. Nishino, Pengukuran dan Alatalat Ukur Listrik. Jakarta: Pradnya Parami, 1976. 